Article

\title{
Undergraduates' Out-Of-Class Learning: Exploring EFL Students' Autonomous Learning Behaviors and Their Usage of Resources
}

\author{
Hui-Chun Hsieh ${ }^{1, *}$ and Hui-Lin Hsieh ${ }^{2}$ \\ 1 Faculty of Foreign Languages, Huaiyin Institute of Technology, Huai'an 223003, China \\ 2 Center for English Language Teaching, Wenzao Ursuline University of Languages, Kaohsiung 807, Taiwan \\ * Correspondence: huihsieh@umail.iu.edu; Tel.: +86-1505-139-4369
}

Received: 31 March 2019; Accepted: 13 June 2019; Published: 26 June 2019

check for updates

\begin{abstract}
Educational research is increasingly paying attention to students' out-of-class learning. Students' out-of-class learning is linked to improved class performance and constitutes an important part of learner development. Prior research has argued that learning-resources provision should encourage students' autonomous learning both in and out of the classroom [Benson, 2013; Benson \& Reinders, 2011; Gardner \& Miller, 1999; Little, 1997; Richards, 2015]. However, work on autonomy often proceeds via generalities rather than focusing on its enactment in individual behavior. Accordingly, this study investigated 35 EFL undergraduates' autonomous learning behaviors and their use of resources of the learning center of a university. Data were collected via email interviews with the participants and examination of their resources-usage records. Content analysis of the interview data, using six categories based on a learner-autonomy model, was used to generate each participant's autonomy score. Spearman rho testing of the relationship between those scores and the students' resources-usage scores suggested a very strong positive relationship between autonomous learning behaviors and overall usage of resources, as well as the variety of those resources used by individuals. Data analysis also revealed that, to varying degrees, each participant's autonomous-learning behaviors (based on qualitative examples) fell into more than one of the six learner-autonomy types. Based on these findings, it is recommended that students be encouraged to learn beyond the classroom through pedagogical activities that link classroom learning to learning-center resources. Based on the findings of this study we make suggestions on pedagogical design with SAC and applications for SACs in other educational contexts.
\end{abstract}

Keywords: autonomous learning; learning resources; out-of-class learning; learning beyond classroom

\section{Introduction}

A growing body of educational literature addresses foreign language teaching and learning beyond the classroom [1-6]. Independent learning beyond the classroom is one of the main factors in determining the quality of a student's learning performance. The argument that students' self-access language learning can lead to autonomy has given rise to questions of learning at the self-access center (SAC) in relation to learner autonomy. Learner autonomy has been found a good quality of learners, and one of the elements that lead to successful learning. In language education, the theory and practice of learner autonomy refers to, broadly, a capacity for independent action that learners can develop in the process of learning, and which they can possess to varying degrees and express in various behavioral modes [7-11]. Its developmental aspect is important pedagogically, given that learner development is a desirable goal of education. To foster learner autonomy, learning-resources provision should be suited to encouraging students' autonomous learning both in and outside the classroom $[6,7,12-17]$. 
According to Holec [9], learner autonomy in foreign language learning can be developed systematically, such as in teacher-led learning modes or in a natural setting, in a self-learning mode. Early studies employed a learning structure in which learners were engaged in self-directed learning with provision of self-access materials, a consultant for learning, and opportunities to speak with a native speaker. Recently educational institutions around the world have established self-access centers (SACs) commissioned with various resources to promote students' language learning beyond the classroom. $[1,7,12,18]$. In addition to the practical reasons, SACs function as a natural setting in which students are enabled to learn independently and increasingly exercise control of their language learning $[9,15,19]$, making decisions regarding aspects of language learning, i.e., what, when and how to learn. An interest of foreign language education is to explore students' autonomous language learning activities utilizing SAC resources. Empirical research on college students' autonomous learning can provide vital information not only about that phenomenon itself, but about a range of institutional, pedagogical, and behavioral factors, both technical and human [7,15,16,20-24]. Previous studies examined the roles of SACs in foreign language learning contexts, while some investigated SAC services and implementation $[9,15,22,25]$. Nevertheless, little is known about what activities individual students do at the SAC and how students' individual, unique interactions with SAC resources affect their language learning experiences. According to Gardener and Miller [15], a key element of self-access language learning concerns interactions between students and learning resources of the SAC. Questions in regard to these issues however could not be answered by questionnaires comprehensively. This study employs techniques of email interviews for data collection from $35 \mathrm{EFL}$ college students to interview their learning experiences at an English self-access center and specifically it investigates what may be possible forms of independent learning of the students using self-access resources. Based on the findings of this study, we make suggestions on pedagogical designs of SAC activities, and applications for SACs in educational contexts outside of Taiwan.

\section{Rationale}

In recent years, the number of English-language learners has grown sharply. Factors for success in language learning vary widely, depending on its purpose and learners' individual characteristics: With those who are highly motivated and able to assume more responsibility for their learning being more likely to succeed $[7,10,21]$. Few people would assert that effective learning could occur in the absence of any out-of-class activities; and active engagement in learning beyond the classroom is perhaps particularly important to students of foreign languages $[4,6,26]$.

Good language learners are found to have motivation, be willing to take responsibility for their own language learning, and be autonomous in their learning. The contexts of language learning in Asian cultures are known to be teacher-authoritative, which encourage obedience to and reliance on the teacher $[19,27,28]$. In the traditional teacher-centered approach, teachers are responsible and take control of every aspect of learning. This tradition has produced language learners who study language merely for the purpose of passing exams, for which they go to the class to learn grammar, leave the classroom to practice grammar exercises, and memorize grammatical rules. This does not include all language learners, but the problem discussed here influences a significant number of learners.

Teachers wishing to improve learners' motivation and thus learning outcomes may also find difficulty in attending to individuals' needs and their learning styles because of limited interaction between the teacher and each student as well as class time each week. Some teachers hope to guide their students' learning outside the classroom because they find it hard to expect promising outcomes of learning from EFL students who go to a two-hour-twice-a-week English class of 30-50 students.

In language education, promotion of students' communicative competence is one of the guiding principles of both pedagogy and curriculum design $[28,29]$. For example, communicative language-teaching approaches focus on students' use of the language in classroom activities such as simulated conversations and role-play [30]. Many teachers also seek to extend students' use of the target language beyond the classroom, since language students will eventually face the challenge of 
communicating under real-life conditions-though increasingly, English is taught in contexts where, outside of the classroom, English input for learners is scarce. One way to increase such input and to provide much-needed out-of-class practice opportunities is to provide learning resources that connect students' classroom learning to the wider world.

\section{Theoretical Perspectives}

During the past decades, methods of language teaching have shifted in a constructivist and student-centered direction. Constructivism emphasizes students' role in learning and sees learning as an ongoing and contextualized process, i.e., the process of constructing meaning and understanding of the world from new information and past experiences in specific contexts [31]. Student-centered approaches, meanwhile, put students' interests, needs and experiences in the first place, and take on the view that learning is enhanced when the content of learning is relevant to the learner to develop their own understanding of the concepts, and when students energetically engage in the process of building their own knowledge. As such, both are intended to address the students' needs, interests and cultural backgrounds. Thus, these require teaching that connects students and resources, provides guidance, and designs activities and assignments that engage learners. [11,19,32].

Since the focus of the practice and theory of language teaching shifted to student-centered approaches, the ability of learners to take an active role in their learning has gained its attention in foreign language education. The fundamental value of a student-centered approach to language teaching is that it helps the learner acquire the skills to learn, with the ultimate goal of establishing lifelong learning [14,28]. An important aspect of learner development is the students being the center of learning. The pedagogical concept is in favor of teaching that ultimately turns control of learning over to learners so that they become empowered to engage in learning. Learner autonomy means, "the ability to take charge of one's own learning" [9] (p. 3). This definition has been widely cited in the literature and seen as fundamental and robust [12,29]. Learner autonomy is characterized as the ability and willingness to learn [33]. In other words, autonomous learners are capable of making decisions concerning objectives, progress, content and methods, monitoring, and evaluation of learning $[7,9]$. Nevertheless, they will participate in teacher-led traditional classroom learning as well as in "self-directed learning" [9].

The construct of language learner autonomy has two crucial aspects of human agency. In Holec's definition, the term "take charge of" indicates the learner as the agent of his learning. Little further points out that the learner displays "a capacity—for detachment, critical reflection, decision-making, and independent action [10] (p. 4)." This presupposes psychological readiness of the learner in displaying capability of self-learning and management of affairs regarding modes of learning [23,34]. Equally important, literature of language development states that learner autonomy is also nurtured in the socially-oriented model of learning [3,16,20,27,35-37]. The Vygotsky's social development theory emphasizes the environments in which social interaction and participation in a learning community is an essential part of learning [38-40]. Therefore, the learner is an active participant in the social processes of classroom learning; hence, the autonomous learner is able to "transcend" what he or she learns in the formal context of classroom to wider contexts $[15,20,35,36]$.

An essential aspect of the construct of learner autonomy is that it is a capacity the learner can develop when engaged in appropriate learning situations [10,30]. Logically, this implies that there are degrees of autonomy; and in the sphere of language learning, research has shown that learner autonomy can take different forms in different contexts, and operate to different degrees as a result of individual learners' characteristics [2]. This requires students to assume partial responsibility in language learning and to have some control over the content and methods of learning [9]. Some studies showed that learners demonstrate positive attitude toward learning autonomy and language development in self-direction learning activities [41,42].

When learning a foreign language, in particular, learners require access to various learning resources outside as well as inside the classroom, and their autonomous language learning is "highly 
sensitive to the availability of resources" [12] (p. 840). In educational settings, self-access-often via self-access centers (SACs) - is seen as a means of encouraging students to learn beyond the classroom $[14,23,26,31,43]$. As a result of the nature of SAC, its roles and functions are largely determined by the contexts in which it is set up and the purposes it is set up for. Self-access centers are often commissioned with provisions of resources and contexts for language learners to have flexible learning in terms of what resources, when and how to learn according to their needs $[8,17,23,25,31,35]$. In the past decades, the roles of SACs in formal educational settings have been changing: From a radical alternative in language teaching and learning, in which learners are primarily self-directed, to a role more supportive of existing language programs; and as such, administrators are paying increasing attention to SAC usage and how it is linked to classroom teaching and learning [18,44].

Literature often refers to self-access language learning approaches, emphasizing language learners' interactions with learning resources within the SAC environment, in relation to classroom learning but working independently of teachers $[10,28,30,33,36]$. To this end, foreign language teaching approaches utilize self-access resources, such as multimedia, facilities, consultation services, and language learning sessions, as supplementary material to adequately support students in independent learning. In a self-access mode, the learner assumes certain control of his or her learning and through opportunities to exercise decision-making, develops the ability to "transcend" what he or she learns to the wider world. Increased attention is paid to the SAC usage linked to classroom teaching and learning as a mean for teachers' and students' utilization. In the present study, the focal learning resource center was located on the campus of a college of languages in Southern Taiwan. A free-standing unit, the center provided open and cost-free language-learning resources to students of the university.

The above theoretical views are the underlying rationale of the framework of learner autonomy for the current study.

\section{Learner Autonomy: An Operational Framework}

The present study employs an autonomy framework built based on Littlewood's definition of autonomy and the reasons are two fold. In the context of this study, the SAC is a free-standing unit in a formal educational setting, providing open and free language learning resources accessible to students. Students are welcome to come to utilize the center to learn English beyond the classroom. Furthermore, in order to foster students' communicative competence, use of English is encouraged or required in activities or at learning sessions. In order to understand students' language learning activities and SAC usage, the autonomy framework is used as a conceptual tool in analyzing the interview data of participants' autonomous learning.

Although learner autonomy can be a multidimensional concept, it "is manifested in the form [12] (p. 840)" that learning takes, both in the specific sphere of language learning and in general [10]. However, while scholars express broad agreement that different degrees of autonomy exist $[7,15,17,28$, 30], how to measure these degrees remains unclear. Therefore, it is necessary to build a framework for doing so. However, learners can have an 'inner', 'latent' or 'potential' capacity for autonomy, but measurement to this natural attribute seems unfeasible [10]. Proceeding from Little's suggestion that we can recognize autonomous learners by their learning behaviors, research on degrees of autonomy could measure overall learner autonomy by aggregating the autonomy levels of separate learning behaviors [10]. In this study, the learner-autonomy framework is built with six lenses to accommodate different kinds of learners in various contexts, although it may not be an exhaustive list of components of learner autonomy in foreign language learning.

Language learner autonomy relates to two main components "willingness and ability" of autonomous learners who are capable of "mak[ing] and carry[ing] out the choices which govern his or her actions" [33] (p. 428). These two components of learner autonomy, further divided into motivation and confidence, and knowledge and skills, are used for analyzing students' perceptions of their learning activities at the SAC. In language learning and teaching, language learning goals mean language proficiency. Learner autonomy in foreign language learning is the learner capability 
to learn away from institutional programs. That is, autonomy as a communicator is one component and autonomy as a learner is another. In terms of autonomous learning activity, proactive learners are self-initiated and have more control over learning; in comparison, reactive learners are responsive to a task and take on necessary work.

Accordingly, the present study's analytical framework is built on prior research by Littlewood [28,33], and includes three parts: Features of learner autonomy, domains of autonomy, and levels of autonomy, which can further be divided into six rubrics (or categories): (1) Learning beyond the classroom, (2) learning on one's own volition, (3) autonomy as a communicator, (4) autonomy as a learner, (5) proactive autonomy, and (6) reactive autonomy. The features, domains and levels of autonomy established by these rubrics in the case of EFL (English as a foreign language) are shown in Table 1 below.

Table 1. Features, domains and levels of EFL ${ }^{1}$ learning autonomy.

\begin{tabular}{lll}
\hline \multicolumn{1}{c}{ Learner Autonomy } & & \multicolumn{1}{c}{ Subcategory } \\
\hline \multirow{2}{*}{ Features } & - & Taking responsibility of one's own learning \\
& $\bullet$ & Taking ownership (partial or total) of one's own learning \\
\hline \multirow{2}{*}{ Domains } & - & Autonomy as a communicator \\
& - & Autonomy as a learner \\
\hline \multirow{2}{*}{ Levels } & - & Proactive autonomy \\
& $\bullet$ & Reactive autonomy \\
\hline & &
\end{tabular}

These six categories of autonomous language learning are further defined in the following. Features of learner autonomy

- Students should take responsibility for their own learning, and an active role in it by doing activities which enable learning beyond the classroom.

- $\quad$ Taking responsibility involves learners taking ownership (either partial or total) of their learning. They engage in learning activities of their own volition, actively, and for pleasure.

Domains of learner autonomy

- Autonomy as a communicator is the ability to use the language creatively and to use appropriate strategies for communicating meanings in specific situations.

- Autonomy as a learner is the ability to engage in independent work (e.g., self-directed learning), and to use appropriate learning strategies, both inside and outside the classroom.

Levels of learner autonomy

- Proactive autonomy regulates the direction of activity as well as the activity itself. It enables learners to take charge of their own learning, determine their objectives, select methods and techniques and evaluate the knowledge and skills that have been acquired.

- Reactive autonomy regulates the learning activities once the learning activity's direction has been set. It does not create its own direction but, once a direction has been initiated, it enables learners to organize their resources autonomously in order to reach their goal. It can be either a preliminary step towards proactive autonomy or a goal in its own right.

\section{Research Questions}

There have been some previous studies of SACs roles in autonomous foreign-language learning, amid a somewhat larger body of work on the services and resources SACs provide. However, little is 
yet known about how learning activities in SACs affect individual learners' language skills or learning development. Accordingly, this study is guided by the following research questions:

1. What are the interrelationships between EFL students' autonomous-learning behaviors and their usage of SAC resources?

2. What forms of autonomous learning are facilitated by specific SAC resources?

\section{Methodology}

\subsection{Research Design}

The present study explores EFL students' learning activities and use of the self-access center (SAC) in a university in Taiwan. The study is to interview students users of the SAC about what motivate them to use the center, what activities they do and how students perceive their learning in terms of effectiveness. To do so, after permission was obtained from the head of the center, the recruitment of participants was conducted at the reception desks via the staff members, as it was the SAC staff that received students and organized appointments for learning sessions. The researchers were not directly involved in the recruitment phrase in order to avoid pressuring the students, and, in doing so, the researchers did not want to use an authoritarian figure (i.e., a teacher) to carry out the recruitment. In a period of two weeks, students who used the center at least two times were send email with interview questions. The email-interview stage was designed to collect students' narratives of their English-learning activities and their use of the SAC. Other qualitative approaches that were employed are participant observation, informal interview with center's staff, documents, in-depth description of the context of study. After data collection, interview word files were created for each participant. To study the participants' learning experiences and resources that were mostly used, content analysis was used to analyze the email interview data. In order to investigate students' autonomous language learning behaviors in relation to their use of the SAC's resources, a framework based on Littlewood $[28,33]$ was used to analyze informants' email interviews. Data were coded by six categories and rated to produce autonomy scores. Participants' SAC use records were obtained and used to produce SAC use scores. Spearman's rho statistical analysis was used to examine the correlation between use of the SAC and autonomous behaviors.

\subsection{Setting and Participants}

The study set on its locus of the natural setting — the learning resource center (SAC) of a college of languages in the suburban areas of a major city in Southern Taiwan. The center provided open and cost-free language-learning resources to students of the university. The research site of this study will be at the English Learning Center (ELC) at Wenzao Ursuline University of Languages (WZU). WZU is atypical for its five-year programs. Another factor that makes the college a setting of an EFL study is that the five-year programs are all, and only, language departments, admitting graduates from junior high school. Students are competitive to enter the programs for language courses demanded of these programs. These junior college students comprised the largest group of the language majoring students. The students are usually between age 16 and 20 and according to the program curriculum, take $12 \mathrm{~h}$ of English language courses in the first three years. This is much more hours than the typical freshman English courses of non-language majoring students at the university. As for the university freshman, English language programs usually require a two-hour EFL class in addition to one-hour lab each week.

The English Teaching/Learning Resources Center in Southern Taiwan, organized by WZU, has a website. The section on Teaching Resources includes English Teaching Treasure Island, teacher forum and chat room, a discussion board, and English Teaching e-monthly. The section on Learning Resources includes a Reading Station, E-book-review, and E-paper weekly.

At the language learning center, the services provided for students learning English include oral practice, writing consultation, and remedial teaching. It was equipped with learning resources 
and composed of four areas, Movie Circle, Test Preparation area, Listening Section and Reading Lounge. The English Learning Center provides services such as Writing Consultation, Remedial English, Oral Practice, and Drop-In Advising. There are many (more than 15 teachers who take turns) consultants who provide information about grammar rules, the conventions of writing academic papers, and strategies for composing and editing. The remedial English section is to provide academic support services to all students in various English classes. The session of oral practice is for students who want to improve their speaking as well as to perfect their oral language proficiency and fluency. The drop in service is for students to drop by whenever they need help with their English learning.

In keeping with the MOE's policy of promoting students' English proficiency, colleges and universities generally require students to pass the College Student English Proficiency Test (CSEPT). At some schools, high CSEPT or TEOFL scores are used to waive some English course requirements. The level is higher for English majors than for other students. Students who get low-test scores may have to take additional non-credit English courses in order to graduate.

Regarding college teachers' involvement in students' learning activities, pointed out by a teacher in an interview, the teachers and students had developed ties as a community. Informal interviews and observations about SAC use (the self-access resource center) for classroom teaching and learning revealed that a proportion of half of the faculty of the English department made class work linking classroom learning to use of the resources center. The close relationship between teachers and students and among students affected students in their learning.

The school serves as the southern English Teaching/Learning Resources Center, a project funded by the Minister of Education. WZU is known for its practice of a whole language approach to EFL curriculum. WZU has received government grants and established a Language Diagnostic \& Consulting Center, English Learning Center, and English Self-access Center. These centers have counseling teachers that help students and hold learner workshops on such things as learning strategies from time to time.

Permission was obtained from the head of the SAC to distribute questionnaires and interview students. A human subject approval was obtained from the Indiana University-Bloomington to conduct this study. Information of the purpose of this study as well as their rights as study participants was provided to the students before they agreed to complete the questionnaire and email interviews. The participants were aware that they would be interviewed via email about their learning experiences at the SAC. Recruitment of participants proceeded in phases. At the center, staff at the reception desk routinely gave student visitors an information sheet that explained the study's purpose and invited them to fill out a demographic questionnaire.

There were 122 questionnaire respondents, among whom 78 signed up for email interviews; in the end, 35 completed them. The participants comprised Taiwanese college students from various years of the college programs, all of whom volunteered to participate. Their ages ranged from 15 to 22 (all female, of which $82 \%$ were 15 to18). The participants had used the SAC resources for various lengths of time. Of these 35 students who had responded to the email interviews, 23 were classified as experienced users of the SAC, and the remainder, novice users (defined as having used the center fewer than five times). All personal names have been changed to protect the participants' anonymity.

\subsection{Instrument and Procedure}

In this study, the mode of email-interview was employed to collect students' narratives of their English-learning activities and their use of the SAC. It allowed in-depth interviews of interviewees' experiences in replying to the interview questions that asked the participants to reflect on their self-access learning activities and use of SAC resources. Interview questions were emailed, by the first researcher, to the 78 of the 122 questionnaire respondents who had (1) agreed to an email interview and (2) used the center's resources or attended learning sessions there two or more times.

Of the 35 students who completed the email interviews, most of them were interviewed in two to four times of correspondence with follow-up questions. Each interview consisted of multiple email 
exchanges. The interview questions evolved over the course of each interview, but mainly focused on (1) what motivated the students to come to use the center, (2) what activities they engaged in there, and (3) what they thought of those activities' effectiveness. To facilitate the students' communication, all interviews were conducted in Mandarin. (Later after data analysis, parts of the email interviews were translated into English for potential inclusion in the report of the study.) There were incentives provided to students in completion of the email interviews. The records of the participants' use of the SAC were tabulated to facilitate tracking the use of the learning resources and accurate record-keeping regarding their activities at the center.

\subsection{Data Analysis}

To begin analysis, the data were read multiple times to find the following: (1) What motivates students to use the SAC, (2) what activities they do, and (2) how effective they judge the learning activities to be. Reading of the data to analyze the characteristics of the messages continued until themes emerged. These themes were used to identify the students' activities at the center. These results were also summarized into Table 3 (See Section 7.3. Activities students do and resources that are mostly used).

To investigate the relationship between the participants' autonomous-learning behaviors and their usage of resources, both qualitative and quantitative data analyses were carried out. To begin with, content analysis was employed to analyze the narrative data from the email interviews. The data were read multiple times and analyzed for evidence of autonomous learning behaviors. To produce autonomy scores, the resulting data were coded into six categories of autonomous learning: (1) Learning beyond the classroom, (2) learning on one's own volition/decision, (3) autonomy as a communicator, (4) autonomy as a learner, (5) proactive autonomy, and (6) reactive autonomy [28,33], and rated on an ordinal scale of measurement (either one, two, or three points, on never, sometimes, or always).

Next, to obtain resources-usage scores, the center's logs of individual student activity were analyzed for the numbers of times they attended learning sessions, how often they used the learning materials and facilities, and how many types of activities their email interviews described. One point was awarded to each of these instances. The lowest resources-usage score thus obtained was five, and the highest, 54 .

When the relationship between the students' autonomous-learning behaviors and their usage of SAC resources was investigated, only the experienced users' interview data were applied to the Spearman rho testing because, based on interview data collected from the experienced users, these interviewees can provide more description, that is, detailed than other less experienced users. One additional user was excluded from the analysis because, though an experienced user of the center, he had only visited it during previous semesters. Thus, 22 participants' data were used in the correlation testing. All personal names have been changed to protect the participants' anonymity.

\section{Results}

\subsection{Descriptive Statistics}

To investigate the relationships between students' autonomous learning behaviors and their use of SAC resources, descriptive statistics for the autonomy scores and resources-usage scores were computed, and further analyzed using the non-parametric Spearman rho test. Students were grouped, using the data distribution, into high, low, and middle scores, in order to find out the difference between/among levels of the two variables, autonomy and resource usage. Table 2 lists the descriptive statistics of the three groups' autonomy and resources-usage scores. As indicated, the members of the high-autonomy group were all heavy SAC users, with resource-usage scores ranging from 29 to 54; the middle-autonomy learners scored 11-25 as moderate users, albeit of a wide spectrum of resource types and autonomous behaviors; and the low-autonomy group were all light users of the center, with usage scores all under 10. Overall, the results suggest that the three groups were highly distinct both in 
their degrees of autonomous learning and in their resources usage. The illustration of the three groups' autonomy and resources-usage scores is shown in Table 2.

Table 2. Average usage scores of the high-, middle-, and low-autonomy groups.

\begin{tabular}{cccc}
\hline Autonomy Group (Usage Scores) & Autonomous-Behavior Scores & Range & Median \\
\hline High (29-54) & $13-15$ & 2 & 14.5 \\
\hline Middle (11-25) & $3-12$ & 9 & 10 \\
\hline Low (4-9) & $3-9$ & 6 & 6 \\
\hline
\end{tabular}

\subsection{Correlations}

Spearman's rho tests were also performed to establish the strength and direction of the association between the two variables autonomous behaviors and resources usage. There was a strong, positive and statistically significant correlation between the participants' autonomy scores and their resources-usage scores, with a correlation coefficient of $\rho=0.837$ at $p<0.001$.

The Spearman rho testing also revealed a very strong positive association between autonomous learning behaviors and resources usage. Namely, those students whose learning behaviors rated as highly autonomous were also those who most frequently used more different types of resources. This study also found similarity and difference between novice users and experienced users in their reasons of learning at the SAC, the learning activities, and how they valued the activities.

\subsection{Activities Students Do and Resources that Mostly Used}

The analysis revealed that some students attended more kinds of learning activities than others did, while some other students attended one kind of activity, such as oral practice, more often than other activities. The top three activities undertaken were individual learning, consultation / one-on-one or group tutorials and using the facility and learning materials. In Table 3 are activities that students mostly do and resources that were mostly used.

Table 3. Activities students do and resources that mostly used.

\begin{tabular}{ll}
\hline Activity & Resources \\
\hline \multirow{2}{*}{ Individual learning \& use of resources } & Using special facilities \\
& $\begin{array}{l}\text { Internet resources } \\
\text { Specially installed software }\end{array}$ \\
\hline \multirow{2}{*}{ Consultations / One-on-one or group tutorials } & Oral practice / Free talk \\
& Writing consultation \\
& Remedial teaching \\
\hline \multirow{2}{*}{ Organized programs } & Short-term courses \\
& Workshops \\
\hline
\end{tabular}

- Individual learning and use of facilities or specially installed software

A comparable number of students use the facilities and learning materials at the center. Among the things they do to learn English are:

- $\quad$ Listening exercise as practice for class

- $\quad$ Preparing for tests, or standardized tests such as CSEPT or TOEIC

- $\quad$ Reading English magazines.

At the SAC, the learning resources space has distinct areas of movie circle, listening section, test preparation and reading lounge. The students would utilize the SAC's resources in order to preview or review items for their English classes or complete class work. For these tasks, the students would 
utilize the multimedia, DVDs, satellite programs, on-line resources, storybooks and magazines to learn English. One student, Joanne, stated that she used the English listening exercises that helped her learn the content of the textbook and would repeat several times to improve her comprehension.

Students also came to utilize the center for CSEPT preparation. The students would utilize the SAC for improvement of their general English ability and undertook learning activities to prepare themselves for CSEPT which is a requirement set by the curriculum. Compared to their beginner user counterparts, the experienced users were much more likely to use the center for their own learning needs rather than for class work. The students also used the specially installed software and Internet resources on a regular basis. One student, Chenyi, stated that the grammar software was useful and that she accomplished 365 units in two months. Other students utilized the software to focus on particular English language skills, i.e., learning vocabulary, English pronunciation and listening skills.

\section{- Consultation/one-on-one or group tutorials}

Consultations and one-on-one or group tutorials attracted both beginning and experienced users. These activities they do include:

- $\quad$ Oral practice sessions

- Writing consultations

- $\quad$ Learning consultations

Among these, oral practice was the activity the students most often did. The oral sessions not only help the students practice English, but also provided them with opportunities to ask questions and, therefore, learn new information. While attending the oral practice sessions, the beginners were more apt to pay attention to the vocabulary than other aspects of English language, compared to their experienced user counterparts. For example, one student, Hami, stated that the advice that she was given about how to improve English was "helpful, such as learning vocabulary from contextual clues, not relying on the dictionary and listening by concentrating on key words". It appeared that the counseling role of the teacher was salient at the advice-seeking learning sessions. The experienced users tended to focus on meanings in discussions with the teachers during the oral practice sessions. They provided descriptions within their email interviews of in-depth interactions. In these communicative situations, one consistent aspect of these students' sessions was thematic discussion, indicating an interest and understanding in cultural learning. Several topics that interested the students were food, family and pop culture. For example, the topic of family increased one particular student's interest in learning. One particular student, Peggy, reflected on her oral practice stating that she often discussed her family at these sessions. "The topic grew into interesting questions that I [had] never thought of and [that] enabled me to think about family in a new direction." Peggy continued several sessions of oral practice and stated that following on similar themes helped her learn.

Another activity that many of the students attended was writing consultation. For an appointment of writing consultation, the students were required to hand in their writing work at least two days before. Each session lasted $15 \mathrm{~min}$. According to the students, the teacher gave advice on writing skills as well as pointed out the grammar errors and provided possible ways of corrections. While these sessions were not discussed in detail in the email interviews, the students did state that grammar was an important reason why they attended learning sessions. Some experienced users mentioned attending sessions for help with writing assignments. Grammar correction and English usage often appear in their descriptions on learning during the session. According to the students, the teacher gave advice on writing skills as well as pointed out the grammar errors and provided possible ways of corrections. Some students reported learning writing skills of English compositions; however, while stating a lack of writing skills, the email interviews from the students reflect the idea that the students pay more attention to grammar, vocabulary, and English usage than proper writing skills. Elinor stated, "the more that I wrote, the more quickly I am able to think and write in English," especially in regard to properly constructing sentences. Elinor stated that she also took part in an English composition contest following the end of the writing training course. 
Remedial teaching and learning consultation also attracted students. The purpose of the remedial teaching sessions was to provide help to students with learning English, mostly about the grammar, and learning skills. The students who attended those sessions most often sought assistance with class work. And their focus of learning tended to be vocabulary, word usage, and grammar. The last additional resource that the students utilized was the learning consultation, which is similar to the writing consultation, except that the student must have internet access in order to make an appointment. For example, an experienced user, Chenyi, sought suggestions on articles to read in English in order to challenge her reading comprehension. She stated that "the teacher told me that in addition to reading the articles, I should also write a summary of each article and include a list of vocabulary words that I should then define and memorize."

\section{- Organized programs}

During the semester, workshops were held at the SAC in which the students could discuss, in groups, ways that they found useful in regard to learning English. There were short courses offered often during the semester and the summer/winter breaks and these courses usually lasted between one week and several weeks. To the students, these courses were opportunities to improve their language skills that could not be provided to them during their regular classes. Often, they were related to writing skills, public speaking, pronunciation, grammar or vocabulary. In addition, these courses were free-standing (no credit) courses. The courses included summer camps or writing courses and English composition contests.

\section{Discussion}

This study's results support the existence of strong, positive relationships between students' quantity of autonomous-learning behaviors, on the one hand, and on the other, their (1) overall SAC resource usage and (2) SAC resource-usage variety. The data also confirmed that based on participants' autonomous-behavior scores, fairly fine distinctions can be made between high-, middle-, and low-autonomy groups of Taiwanese undergraduate EFL learners. This provides important empirical support for prior scholars' assertions that autonomous-learning behaviors are not merely present or absent, but exist to some degree or another in all learners. These findings, in turn, tend to confirm the developmental aspects of learner autonomy outlined in the present paper's analytical framework, as well as Benson's views that learner autonomy is manifested in students' modes of autonomous language learning [12], and greatly affected by the availability of resources.

The analysis of the students' activities and learning experiences revealed a variety of situations in which they went self-learning at the SAC. The findings of students' learning activities at SAC and resources that they most often used are summarized as the following. (1) In undertaking learning activities at the SAC, student users often mentioned recommendations from teachers, upper-classmates or friends to explain their first visit to the SAC, confirming the close relationships among administrators, faculty and students reported in interviews. This may also explain why student autonomy is highly responsive to language resources. This suggests that one way to encourage autonomous language learning may be to increase an individual's SAC use by creating a self-access environment in which the student is provided opportunities to use resources and exercise his/her decision-making skills in regard to his/her learning. (2) Class-related learning motivated students to learn at the SAC. They often used the materials in order to review previous class sessions and listen to upcoming class sessions in order to improve her/his understanding of the information being taught; such as for fulfilling the requirement of class work or improvement of general English language ability. (3) Other beginning users who felt that they were behind the others in their class also mentioned the CSEPT requirement as part of their motivation for using the SAC. While they had four years to complete this requirement, the students felt the pressure of the CSEPT and wanted to start studying as early as possible. This indicates that the requirement by school curriculums influentially guide students as one of the goals of study at the university. (4) Students attend oral practice or writing consultation to learn English language skills as 
well as take the opportunity to consult learning English. A need of guidance for learning English or advice on skills for learning in general is what the students seek at learning sessions. The teachers giving counseling/learning sessions at SAC are also instructor teachers who teach classes. For the students, the teacher at the center was a helper and advisor, indicating a change of the traditional role of teachers.

In this study, class work assigned by the teacher was linked to learning activities in the SAC. On the other hand, innovative activities can be used by the classroom teachers to encourage students to learn beyond the classroom. Based on the findings we made the following suggestions on teaching. (1) When designing class assignments for which students should utilize SAC resources, provide counseling and learner training. Language teachers, acting judiciously can make the integration of SAC into their courses advantageous. (2) Use CSEPT preparation exercise-sets (mock questions) in tests. Students are motivated to use the listening and reading practice resources to prepare for class quizzes. (3) Award students to completion of a number of learning sessions at SAC, such as awarding credits or by using a learning passport. (4) Class time for students to share their learning experiences or ways of utilizing the SAC. Students may not be aware of the SAC resources. (5) Refer students who are behind to remedial teaching or learning consultation sessions. (6) Use a class project to induce students to utilize the SAC resources. To maximize accommodation of a variety of learning styles, activities should be flexible.

\section{Conclusions}

This study found similarities and differences between the novice and experienced SAC users in terms of their reasons for learning there, the learning activities they chose, and how they valued such activities. The findings showed that there was a strong relationship between SAC use and autonomous language-learning behaviors, and that those students with more such behaviors used a broader array of SAC resources than their less-autonomous counterparts. Based on these findings, it is recommended that students be encouraged to learn beyond the classroom through pedagogical activities that link classroom learning to learning-center resources. However, the data were not sufficient to provide a clear explanation of whether these were results of using the center, or merely a reflection of high-autonomy students' disproportionately high usage of it, which could have been driven by a variety of personal, social, and other factors. Further research is thus required to establish whether students can become more autonomous through learning in SACs. For instance, researchers can assess whether any changes occur during students' self-access language learning, via interviews and surveys of their perceptions of their responsibility for their learning and learning activities, conducted every two to four months over a long period. This study was subject to the limitations of generalizability that attend small-scale qualitative studies. Generalization of the results to stand-alone self-access resources may be conditional. This study involved translation from Mandarin to English for parts of the email interviews that were translated into English for potential inclusion in the report of the study. We acknowledge the limitation on translation of one language into another. As a result of language differences, word for word translation between two languages was not always possible. Despite these limitations this work does document various ways of interactions between students and learning resources of the SAC. Using email interview data, analysis of the students' narratives of learning revealed more detail about the crucial part of the learning process. While not every email respondent was doing so, some in email interviews were able to reflect on their communicative experiences but also how to learn. Learning to learn is an important element of autonomous learning [10]. Analyzing the learning process is a crucial step to understanding the nature of students' learning activities. Lastly, the findings on various activities students would undertake and their learning experiences at the SAC could provide information about how SACs may support students' language learning beyond classroom.

\subsection{Innovation of Out-of-Class Learning}

In this study, the innovation of out-of-class learning is that action projects were undertaken by more experienced students exercising more freedom of choices on their activities. It was one example 
of students' use of the SAC's resources in ways that might encourage growing learning autonomy. Third-year students have less required class hours than first- or second-year students and, therefore, have more free time between classes. Given that the project was for a class on Personality and Cultivation, it was used by the class teacher to induce independent learning. The project gave students an assignment for which students were required to plan and carry out an action project of self-directed learning (using the SAC resources). Students in paired first wrote a proposal regarding the goals of their learning and how they would implement learning activities and then evaluate learning progress. The teacher held meetings with each pair of students to discuss and counsel their learning and possible modification of actions. At the end, students would need to hand in a report on their learning with reflection on the learning activities and evaluation of their progress. Students were enabled to plan and carry out various activities to achieve their goals: Improving their English ability and regaining passion to learn. The class project included participation in oral practice, workshops (or short course) and study groups as well as utilizing the on-line learning software. Enacting paired learning contributes to their abilities to manage their learning activities and time and become independent learners. One of the students further stated that undertaking learning at the SAC enabled her to learn in various ways and it allowed her to work with another student. Students became increasingly aware of themselves as learners in the process of independent learning.

\subsection{Applications for SACs in Other Contexts}

Based on the findings, we made suggestions that may inform on the implementation of SACs beyond the contexts of Taiwan. (1) Need analysis can be the first step for a SAC to serve users for language learning. One way is to conduct a survey of potential users' needs for using SAC in language learning. (2) Foreign language students may need to prepare for proficiency tests that is required by college at graduation and may be used for job applications. Preparation exercise-kits or software for standardized tests provide students' needs for test preparation. (3) Oral practice and writing consultation are learning sessions that students seek for opportunity to hone their language skills through interaction with native speakers [45]. Taking part in oral practice to do free talk or discussions attracts students to utilize SAC. The literature often states that in order to learn language effectively and become communicatively competent, learners need to be aware of language learning processes and the culture of the target language [4]. (4) Teachers are in an advantageous position to introduce self-access to the students and encourage them to undertake self-access language learning [46]. A connection between classroom teaching and SAC use for class-related learning encouraged SAC use. There should be a closer relationship between self-access learning and classroom based learning [15]. This might be addressed by teachers allocating class time for students sharing their learning experiences at the SAC. (5) A training session or lead-in briefing (introduction to the SAC use) can help users with first time walk-in. Orientation to the SAC is important for a new user. Such orientation classes not only introduced the students to the instructors, but, also, introduced them to the opportunities available at the center, including the resources available and how to use them. (6) Planning short-term courses during the semester, such as workshops, usually a half-day or less, in which participants discuss, in groups, ways of learning English that they found useful. Often these are about writing skills, public speaking, pronunciation, grammar or vocabulary. These courses were non-credit courses, offering opportunities to improve language skills beyond what could be provided in regular classes. For this reason, taking these courses is less stressful than taking regular courses. (7) Regulations include use policy, whole language policy (English-only policy); accessibility, open hours, how to make an appointment or option of drop-in talk, and if a topic selected is required, or free talk, for some students may prefer spontaneous interactions that come from not preparing to be more enjoyable. A successful center will attempt to make learner development an ongoing cycle of action and reflection and to offer a development program that keeps pace with the learners as they work $[31,47,48]$. 
Author Contributions: Conceptualization, H.-C.H.; methodology, H.-C.H.; software, H.-C.H.; validation, H.-C.H.; formal analysis, H.-C.H.; investigation, H.-L.H.; resources, H.-L.H.; data curation, H.-C.H.; writing-original draft preparation, H.-C.H.; writing-review and editing, H.-L.H.; visualization, H.-C.H.; supervision, H.-C.H.; project administration, H.-L.H.; funding acquisition, H.-L.H.

Acknowledgments: The authors greatly appreciate the assistance from the staff at the English Learning Center of Wenzao Ursuline University of Languages, Taiwan.

Conflicts of Interest: The authors declare no conflict of interest.

\section{References}

1. Benson, P. Language learning and teaching beyond the classroom: An introduction to the field. In Beyond the Language Classroom; Benson, P., Reinders, H., Eds.; Palgrave Macmillan: Basingstoke, UK, 2011; pp. 7-16.

2. Benson, P.; Reinders, H. (Eds.) Beyond the Language Classroom; Palgrave Macmillan: Basingstoke, UK, 2011; pp. 7-16.

3. Murray, G. Autonomy in the time of complexity: Lessons from beyond the classroom. Stud. Self-Access Learn. J. 2017, 8, 116-134.

4. Nunan, D.; Richards, J.C. Language Learning beyond the Classroom; Routledge: London, UK, 2015.

5. Reinders, H.; Benson, P. Research agenda: Language learning beyond the classroom. Lang. Teach. 2017, 50, 561-578. [CrossRef]

6. Richards, J.C. The changing face of language learning: Learning beyond the classroom. RELC J. 2015, 46, 5-22. [CrossRef]

7. Benson, P. Teaching Researching Autonomy in Language Learning, 2nd ed.; Pearson: London, UK, 2011.

8. Dickinson, L. Self-Instruction in Language Learning; Cambridge University Press: Cambridge, UK, 1987.

9. Holec, H. Autonomy and Foreign Language Learning; Council of Europe: Strasbourg, France, 1980.

10. Little, D. Learner Autonomy 1: Definitions, Issues and Problems; Authentik Language Learning Resources Ltd.: Dublin, Ireland, 1991.

11. Sinclair, B. Learner autonomy: The cross cultural question. ITEFL Newsl. 1997, 139, 12-13.

12. Benson, P. Learner autonomy. TESOL Q. 2013, 47, 839-843. [CrossRef]

13. Benson, P. Language learning beyond the classroom: Access all areas. Stud. Self-Access Learn. J. 2017, 88, 135-146.

14. Cotterall, S. The pedagogy of learner autonomy: Lessons from the classroom. Stud. Self-Access Learn. J. 2017, 88, 102-115.

15. Gardner, D.; Miller, L. Establishing Self-Access: From Theory to Practice; Cambridge University Press: Cambridge, UK, 1999.

16. Mynard, J.; Stevenson, R. Promoting learner autonomy and self-directed learning: The evolution of a SALC curriculum. Stud. Self-Access Learn. J. 2017, 8, 169-182.

17. Reinders, H. Supporting independent learning through an Electronic Learning Environment. In Supporting Independent Language Learning: Issues and Interventions; Lamb, T., Reinders, H., Eds.; Peter Lang: Frankfurt am Main, Germany, 2006; pp. 219-238.

18. Benson, P. Autonomy in language teaching and learning: State of the art. Lang. Teach. 2007, 4040, $21-40$. [CrossRef]

19. Gremmo, M.-J.; Riley, P. Autonomy, self-direction and self-access in language teaching and learning: The history of an idea. System 1995, 23, 151-164. [CrossRef]

20. Crabbe, D. Fostering autonomy from within the classroom: The teacher's responsibility. System 1993, 21, 443-452. [CrossRef]

21. Dickinson, L. Autonomy and motivation: A literature review. System 1995, 23, 165-174. [CrossRef]

22. Holec, H. Main features of the educational approach adopted. In Learner Autonomy in Modern Languages: Research and Development; Holec, H., Huttunen, I., Eds.; Council for Cultural Co-operation, Council of Europe: Strasbourg, France, 1997; pp. 23-32.

23. Sheerin, S. An exploration of the relationship between self-access and independent learning. In Autonomy and Independence in Language Learning; Benson, P., Voller, P., Eds.; Addison Wesley Longman: New York, NY, USA, 1997; pp. 54-65. 
24. Sinclair, B.; McGrath, I.; Lamb, T. (Eds.) Learner Autonomy, Teacher Autonomy: Future Directions; Longman: Essex, UK, 2000.

25. Benson, P.; Voller, P. Autonomy and Independence in Language Learning; Longman: London, UK, 1997.

26. Crabbe, D. The quality of language learning opportunities. TESOL Q. 2003, 37, 9-34. [CrossRef]

27. Jones, J.F. Self-access and culture: Retreating from autonomy. ELT J. 1995, 49, 228-234. [CrossRef]

28. Littlewood, W. Defining and developing autonomy in East Asian contexts. Appl. Linguist. 1999, $20,71-94$. [CrossRef]

29. Little, D. Language learner autonomy: Some fundamental considerations revisited. Innov. Lang. Learn. Teach. 2007, 1, 14-29. [CrossRef]

30. Nunan, D. Designing and adapting materials to encourage learner autonomy. In Autonomy and Independence in Language Learning; Benson, P., Voller, P., Eds.; Addison Wesley Longman: New York, NY, USA, 1997; pp. 192-203.

31. Gardner, D. The evolution and devolution of management and training needs for self-access centre staff. Stud. Self-Access Learn. J. 2017, 8, 147-156.

32. Nunan, D. The Learner-Centred Curriculum: A Study in Second Language Teaching; Cambridge University Press: New York, NY, USA, 1988.

33. Littlewood, W. "Autonomy": An anatomy and framework. System 1996, 24, 427-435. [CrossRef]

34. Wenden, A. Learner development in language learning. Appl. Linguist. 2002, 23, 32-55. [CrossRef]

35. Dam, L. Learner Autonomy 3: From Theory to Classroom Practice; Authentik: Dublin, Ireland, 1995.

36. Little, D. Learning as dialogue, the dependence of learner autonomy on teacher autonomy. System 1995, 23, 175-181. [CrossRef]

37. Palfreyman, D.; Smith, R.C. (Eds.) Learner Autonomy across Cultures: Language Education Perspectives; Palgrave Macmillan: New York, NY, USA, 2003.

38. Vygotsky, L.S. Mind in Society; Cambridge University Press: Cambridge, UK, 1978.

39. Vygotsky, L.S. Thought and Language; MIT Press: Cambridge, MA, USA, 1986.

40. Wertsch, J.V. Vygotsky and the Social Formation of Mind; Harvard University Press: Cambridge, MA, USA, 1985.

41. Aoki, N.; Smith, R. Learner autonomy in cultural context: The case of Japan. In Learner Autonomy in Language Learning: Defining the Field and Effecting Change; Cotterall, S., Crabbe, D., Eds.; Peter Lang: Frankfurt am Main, Germany, 1999; pp. 19-27.

42. Smith, R. Pedagogy for autonomy as (becoming-)appropriate methodology. In Learner Autonomy across Cultures: Language Education Perspectives; Palfreyman, D., Smith, R., Eds.; Palgrave Macmillan: New York, NY, USA, 2003; pp. 129-146.

43. Reinders, H.; White, C. 20 years of autonomy and technology: How far have we come and where to next? Lang. Learn. Technol. 2016, 20, 143-154.

44. Gardner, D.; Miller, L. Managing Self-Access Language Learning; City University Hong Kong Press: Hong Kong, China, 2014.

45. Little, D. Responding authentically to authentic texts. In Autonomy E Independence in Language Learning; Benson, P., Voller, P., Eds.; Addison Wesley Longman: New York, NY, USA, 1997; pp. 225-236.

46. Lee, I. Supporting greater autonomy in language learning. ELT J. 1998, 52, 282-290. [CrossRef]

47. Sturtridge, G. Teaching and language learning in self-access centres: Changing roles. In Autonomy $\mathcal{E}$ Independence in Language Learning; Benson, P., Voller, P., Eds.; Longman: London, UK, 1997; pp. 66-78.

48. Sturtridge, G. Self-Access. Preparation and Training; The British Council: London, UK, 1992.

(C) 2019 by the authors. Licensee MDPI, Basel, Switzerland. This article is an open access article distributed under the terms and conditions of the Creative Commons Attribution (CC BY) license (http://creativecommons.org/licenses/by/4.0/). 